\title{
Özel ve Kamu Eğitim Örgütlerinde Çalışan Öğretmenlerin Örgütsel Bağlılık Düzeyleri: Etkileşimsel Etki Modeli
}

\author{
DOI: $10.26466 /$ opus. 858602 \\ Lütfi Üredi $^{*}$ - Sait Akbaşl1 ${ }^{* *}$ - Pelin Kösece ${ }^{* * *}$ Buse Özaksoy**** \\ * Doç. Dr., Mersin Üniversitesi, Eğitim Fakültesi, Mersin/Türkiye \\ E-Posta: lutfiuredi@gmail.com \\ ORCID: $\quad$ 0000-0003-1705-1325 \\ ** Prof. Dr., Hacettepe Üniversitesi, Eğitim Fakültesi, Ankara/Türkiye \\ E-Posta: sakbasli@gmail.com \\ ORCID: $\quad$ 0000-0001-9406-8011 \\ *** Dr., Milli Eğitim Bakanlığı, Ankara/Türkiye \\ E-Posta: pelinksc91@gmail.com \\ ORCID: 0000-0003-1795-1323 \\ ****Öğretmen, Doğa Eğitim Kurumları, Ankara/Türkiye \\ E-Posta ozaksoy@hotmail.com \\ ORCID: $\quad \underline{0000-0002-2285-2154}$

\section{Öz}

Bu araştırma, özel ve kamu eğitim örgütlerinde çalışan öğretmenlerin çalıştıları kuruma örgütsel bağlllk düzeylerini, farklı değişkenlerin ayrı ayrı ve ortak etkisi çerçevesinde incelemeyi amaçlamaktadır. Araştırmada ilişkisel tarama modeli kullanılmıştır. Araştırmanın örneklemi seçkisiz örnekleme yöntemi kullanılarak belirlenmiştir. Araştırma 2019-2020 eğitim-öğretim yıl güz döneminde Ankara ilinde özel ve kamu kurumlarında görev yapan 343 öğretmen ile yürütülmüştür. Araştırmada veri toplama aracı olarak Kişisel Bilgi Formu ve öğretmenlerin örgütsel bağlllık düzeylerini ölçmek üzere hazırlanan 15 maddelik iki faktörlü ölçme aracı kullanılmıştır. Verilerin analizinde etkileşimsel etkiyi görmek amacıyla Faktöryel ANOVA, kategorik bağımsız değişkenlere yönelik bağımsız gruplar $t$-testi ve tek yönlü varyans analizi yapılmıştır. Elde edilen bulgulara göre, özel ve kamu eğitim örgütlerinde çalışan öğretmenlerin örgütsel bağhllk düzeylerinin sinıföğretmenleri lehine anlamlı olarak farklılaştı̆̆ı ve çalıştığı okul türüne göre özel okulda çalışan öğretmenler lehine anlamlı olarak farklılaştığı ortaya çıkmıştır. Özel okulda çalışan öğretmenlerin, örgütsel bağlllık durumları yönünden etkili bir performansa sahip oldukları sonucu elde edilmiştir. Elde edilen sonuçlar tartışılmış ve gelecekteki araştırmalara yönelik önerilerde bulunulmuştur.

Anahtar Kelimeler: Örgütsel bağlılık, etkileşimsel etki, eğitim kurumları 


\title{
Organizational Commitment Levels of Teachers Working in Private and Public Institutions: The Interactive Impact Model
}

\begin{abstract}
The purpose of the research to examine the organizational commitment levels of the teachers working in private and public educational organizations within the framework of the separately and common effect of different variables. Relational model was used in the study. Random sampling method which is the one of the probability sampling methods has been used in the study. The research that carried out with totally 343 teachers working in public and private education institutions in Ankara in the first term of 2019-2020 academic year. Personal information form and two-factor measurement tool consisting of 15 items prepared to measure the organizational commitment levels of teachers were used as data collection tools in this study. The data was analyzed by using Factorial Anova, independent groups t-test for categorical independent variables and one-way analysis of variance to see the interactional effect. According to the findings, the findings revealed that the organizational commitment levels of teachers working in private and public educational organizations significantly differantiated in favor of classroom teachers and significiantly differantiated in favor of teachers working in private schools. It is concluded that teachers working in private schools have an effective performance in terms of organizational commitment. The results were discussed and recommendations for future research were offered.
\end{abstract}

Keywords: Organizational commitment, interactional effect, educational institutions 


\section{Giriş}

Bir örgütün hayatta kalması için, işgörenlerin örgüte bağlılıklarının devam etmesi gerekmektedir. Örgüte olan bağlılık duygusu, çalışanların performansını ve dolayısıyla da örgütün performansını pozitif yönde etkileyecektir. Örgütte görülen disiplin problemlerinde azalma, devamsızlıkta azalma, daha çok üretim ve daha yüksek verim elde etmek için çalışanların örgütsel bağl1lık düzeylerinin mümkün olduğunca yüksek olması gerekir.

Örgütsel bağlllık kısaca, işgörenin örgüte karşı olan sadakatidir ve çalıştığ1 örgütün başarısı için gösterdiği ilgidir (Bayram, 2005). Literatürde dürüstlük, özveri, bağllıı gibi çalışanların örgüte karşı tutum ve bağlılıkları kapsamında farklı sınıflandırmalar yapılmıştır (Berberoğlu, 2018). Örgütsel bağl1lık için yapılan sınıflamaların temel amacının örgüt performansını artırmak olduğu söylenebilir. Örgütsel performans, yönetim biliminde temel kavramlardan biridir ve yönetimin görev ve davranışları çoğunlukla bu anlayışa göre şekillenir (Nikpour, 2017). Örgütlerine bağlllıkla çalışanlar da karakteristik olarak o örgütün hedef ve değerlerine güçlü bir inançla sahip çıarlar. Bu çalışanlar örgütleri adına çaba göstermeye isteklidirler (Ahuja ve Gupta, 2019). Bu tarz çalışanları olan örgütlerin performans ve üretimsel verimliliği daha yüksektir. Çünkü örgütsel bağlllı̆̆ yüksek olan insanlar için bulundukları kurumda çalışmak önemlidir ve kendilerini o kurumun bir parçası olarak gördükleri için görevlerini yerine getirirken tutarlı davranırlar. Ayrıca bu çalışanlar hem kendilerinin hem de kurumlarının daha iyi olması için önemli tecrübeler kazanırlar (Faraji ve Begzadeh, 2017). Bahsi geçen özellikleri taş1yan çalışanlara sahip olmak, tüm örgüt türleri için önemli bir kazanımdır.

Performansin ve verimin önemli olduğu örgütlerden birisi de eğitim örgütleridir. Eğitim kurumlarının çalışanları konumunda olan öğretmenlerin örgütsel bağlllık düzeyleri, bulundukları kurumun ilerlemesinde önemli rol oynar. Öğretmenlerin örgüte bağlılığı iş performansı açısından önemli doğurgulara sebep olur (Çoban ve Demirtaş, 2011). Son yıllarda araştırmacılar araştırmalarını, okulların etkili eğitimin gerçekleştiği ortamlar olmasını sağlamak için bu durumun önündeki engelleri ortaya çıkarmak ve çözüm yolları bulmaya yoğunlaştırmıştır (Korkmaz, 2011). Yapılan araştırmalarda öğretmenlerin örgütsel bağlılık düzeylerinin farklı değişkenler doğrultusunda ele alındığı görülmektedir. Yapılan bazı araştırmalar öğretmenlerin örgütsel bağlılık düzeylerinde yaş, cinsiyet, kıdem, medeni durum, sendika üyeliği, 
branş değişkenlerini ele almıştır (Durna ve Eren, 2005; Çetin Gürkan, 2006; Çolakoğlu, Ayyıldız ve Cengiz, 2009). Sarıdere'nin (2004) araştırmasında öğretmenlerin, örgütsel bağlılığın duygusal ve devam boyutları ile işten ayrılma niyeti arasında negatif ilişki anlamlı bulunmuştur. Uğurlu ve Üstüner'in (2011) araştırmasında öğretmenlerin örgütsel bağlllıklarının temelinde yöneticilerinin etik liderlik davranışları sırasında örgütsel adaleti sağlamaları etkili bulunmuştur. Yurt dışında yapılan araştırmaların da eğitim örgütlerinde örgütsel bağllıık düzeylerini ortaya çıkarmaya ve artırmaya yönelik olduğu görülmüştür. Roncesvalles ve Gaerlan'ın (2020) yükseköğretimde gerçekleştirdiği araştırmasında yöneticinin otantik liderliğinin öğretmenlerin moralini ve örgütsel bağlılığını olumlu etkilediği ortaya çıkmıştır. Dou, Devos ve Valcke'nin (2017) araştırmasında öğretmenlerin iş tatmini ve örgütsel bağl1lığı üzerinde öğretimsel ve dönüşümsel liderliğin önemli bir etkisi olduğu sonucuna ulaşılmıştır. Benzer şekilde John ve Taylor (1999) da araştırmalarında örgütsel bağlılığın yöneticinin liderlik tutumlarından etkilendiğini ortaya koymuştur ve araştırmada kişiyi dikkate alan liderlik tarzına sahip müdürlerle çalışan öğretmenlerin örgütsel bağlllık düzeyleri daha yüksek bulunmuştur. Scholl (2008) ise bir örgütte uzun zamandır çalışmanın örgütsel bağlılık üzerinde etkili olduğunu belirtmiştir.

\section{Öğretmenlerde Örgütsel Bağlılık}

Öğretmenlerin örgütsel bağlllığı, mesleği anlama ile başlayıp mesleki rolleri kabul etme, öğretme doyumuna ulaşma, okul tarafından kabullenilme ve iş doyumunu sağlama ile gerçekleşir (Celep, 2014). Öğretmenlik, içerisinde pek çok farklı boyutu ve örgütsel bağlılığ1 etkileyen faktörü barındıran bir meslektir. Eğitim örgütlerinin iş/akış süreçlerinin her aşamasında insan ögesi yer almaktadır. Bu nedenle insan ögesi, eğitim örgütlerinde önemli bir yere sahiptir. Rosenholtz ve Simpson (1990), öğretmenlerin örgütsel bağlllıkları istenen seviyeye ulaşmadığında, okula karşı olumsuz tutum geliştirme, işe gelmeme ya da işten ayrılmaya istekli olma durumlarının oluşacağını belirtmiştir. Chor (1991), öğretmenlerde örgütsel bağlllık sürecini, olumlu ve olumsuz etkileri olabilen farklı faktörlere bağlamıştır. 


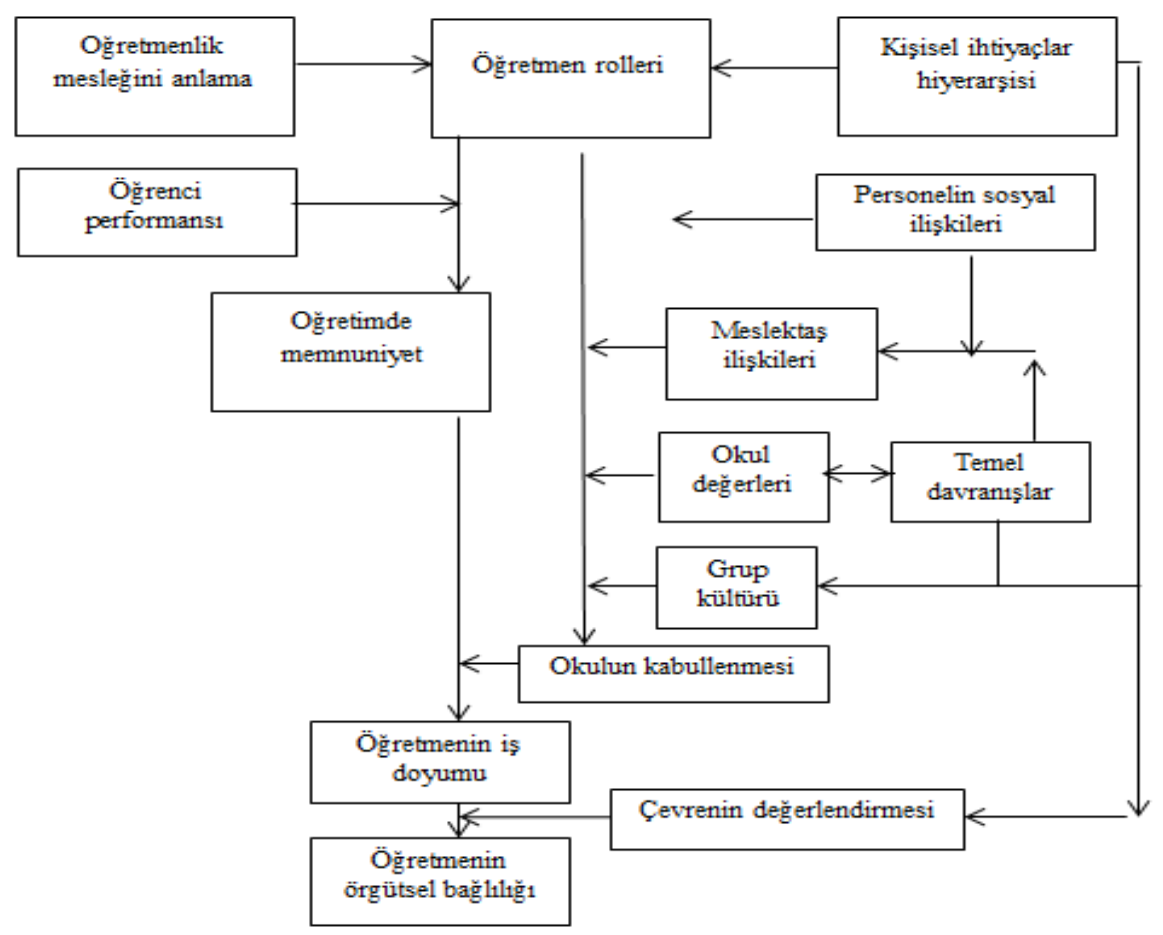

Şekil 1. Öğretmenlerin Örgütsel Bağlılık Süreci (Chor, 1991)

Tüm bu faktörler öğretmenin tam örgütsel bağlıllı̆ını sağlamak ve bunu sürekli hale getirmek için dikkate alınmalıdır. Öğretmenlerin mesleki coşku ve enerjilerini devam ettirebilmeleri için mesleki bağlılıklarının olması gerekir (İlter, 2019).

\section{Araştırmanın Önemi}

Günümüzde ekonomik, sosyal, kültürel, bilimsel pek çok alanda durağan olmayan bir değişim ve gelişim söz konusudur. Bu gelişmelerin toplumda doğrudan etkilediği öge konumunda olan insanlardan beklenen beceriler de değişmektedir. Toplumları etkileyen en önemli kurumlardan biri olan eğitim kurumlarının her biri kendi içerisinde eğitim örgütlerini oluşturmaktadır. Eğitim örgütlerinin temel ögelerinden biri olan öğretmenlerin örgütsel bağl1lığı, eğitim kurumunun ilerlemesine ve gelişmesine önemli derecede etki 
eder. Cinsiyet, medeni durum, yaş, kıdem değişkenlerinin öğretmenlerin örgütsel bağlılıkları üzerine farklı derecelerde etki ettiği yapılan araştırmalarda görülmektedir. Bu değişkenlere ek olarak kurumdaki hizmet süresi ve kıdemin ayrı ayrı ele alındığı, değişkenlerin ortak etkilerinin örgütsel bağlılık üzerindeki etkilerinin incelendiği ve sınıf ya da branş öğretmeni olmanın örgütsel bağlılık üzerindeki etkisinin incelendiği bu araştırmanın, literatürdeki boşluğu doldurmaya katkı sağlaması beklenmektedir. Bu araştırma; farklı değişkenlerin etkileşimsel etkisini, özel-kamu kurumunda çalışma, kıdemokuldaki hizmet süresi ve sınıf-branş öğretmeni olmayı ayrı ayrı ele aldığı için önemlidir. Elde edilen sonuçların, öğretmenlerin mesleki gelişim çalışmalarına kaynak teşkil edeceği düşünülmektedir. Araştırmada şu alt sorulara yanıt aranmıştır:

- Çalıştığı kurumda farklı hizmet sürelerine sahip sınıf ve branş öğretmenlerinin örgütsel bağlılık düzeyleri arasında anlamlı bir fark var mıdır? (BxH)

- Farklı yaş grubunda yer alan kadın ve erkek öğretmenlerin örgütsel bağlılık düzeyleri arasında anlamlı bir fark var mıdır? (YxC)

- Çalıştığı okul türü, medeni durum, eğitim düzeyi ve mesleki kıdemin öğretmenlerin örgütsel bağlılık düzeyleri üzerinde anlamlı bir etkisi var mıdir?

Yukarıdaki araştırma sorularına dayanarak, önerilen araştırma çerçevesi bu çalışma için Şekil 2'de gösterilmiştir.

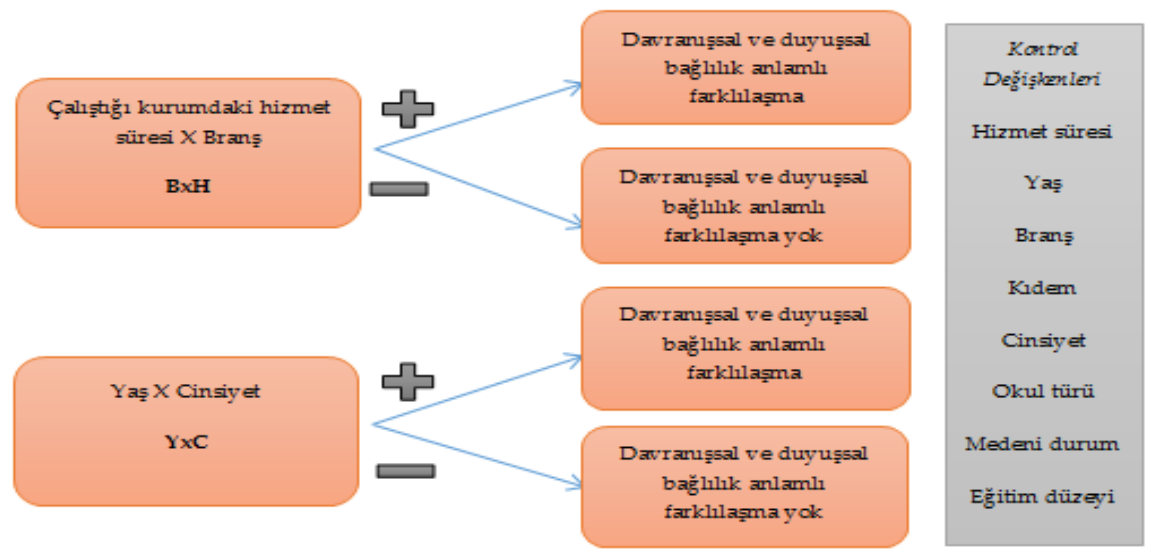

Şekil 2. Değişkenler ve örgütsel bağhlik arasındaki ilişkinin etkileşimsel etki model 


\section{Yöntem}

Bu araştırmada nicel araştırma yöntemleri kullanılmıştır. Eğitim kurumlarında çalışan öğretmenlerin örgütsel bağllılı düzeyleri üzerinde bazı değişkenlerin etkileşimsel etkisi, ilişkisel tarama modeli kullanılarak incelenmiştir. Nicel yaklaşımlarda "bir durumun açıklanmasında, duruma egemen olan ilişkiler ağı sınırlı sayıdaki bir dizi değişkene ve bu değişkenler arası ilişkilere indirgenerek açıklanır" (Yıldırım ve Şimşek, 2013; s.64). Bu değişkenler bağımlı ve bağımsız değişken olarak isimlendirilir. Bu çerçevede araştırmanın bağımlı ve bağımsız değişkenleri arasında karşılaştırmalı incelemeler gerçekleştirilmiştir.

\section{Örneklem}

Araştırmanın evrenini Ankara' da özel ve kamu okullarında görev yapan öğretmenler oluşturmaktadır. Araştırmanın örneklemi belirlenirken olasılık temelli örnekleme yöntemlerinden seçkisiz örnekleme kullanılmıştır. Büyük olan evrenin tümü çalışılamadığı için evreni temsil eden, daha küçük ve çalışlabilir bir grup seçilmiştir. Araştırma kent düzeyinde yapıldığ 1 için, yaklaşık 55.000 kişilik evrenden .05 sapma miktarına göre örneklem belirlenmiştir. Araştırma verileri 2019-2020 eğitim-öğretim yılının güz döneminde toplanmıştır. Katılımcılar gönüllülük esasına göre belirlenmiştir. Araştırma öncesinde katılımclara, elde edilen verilerin sadece bu araştırma kapsamında kullanılacağı ve bilgilerin gizli tutulacağına yönelik bilgilendirme yapılmıştır. Örnekleme ait bazı bilgiler Tablo 1'de gösterilmiştir.

Tablo 1. Katılımcıların Cinsiyet ve Çalıştıkları Okul Türüne Göre Dağılımı

\begin{tabular}{llll}
\hline Cinsiyet & & & \\
\hline Okul Türü & Kadın & Erkek & Toplam \\
\hline Özel & $197(\% 82.8)$ & $95(\% 88.8)$ & $292(\% 84.6)$ \\
Kamu & $39(\% 16.5)$ & $12(\% 11.2)$ & $51(\% 14.9)$ \\
Toplam & $236(\% 69)$ & $107(\% 31)$ & $343(\% 100)$ \\
\hline
\end{tabular}

Örneklemde Tablo 1'e göre, özel okulda çalışan 292 öğretmen ve kamuya bağlı okullarda çalışan 51 öğretmen yer almaktadır. Kadın katılımcılar tüm örneklemin \%69'unu ve erkek katılımcılar tüm örneklemin \%31'ini 
oluşturmaktadır. Araştırmanın örnekleminde yer alan öğretmenlere ait diğer sosyo-demografik bilgiler Tablo 2'de gösterilmiştir.

Tablo 2. Katılımcılarn Sosyo-Demografik Özelliklerine Yönelik Frekansları

\begin{tabular}{|c|c|c|c|}
\hline Değişken & Frekans (\%) & Değişken & Frekans (\%) \\
\hline Yaş & & Kıdem & \\
\hline 20-30 & $135(\% 39.4)$ & $1-5$ yil & 97 (\%28.3) \\
\hline $31-40$ & $145(\% 42.3)$ & 6-10 yil & $124(\% 36.2)$ \\
\hline 40 yaş üzeri & $63(\% 18.4)$ & 10 yıl üzeri & $122(\% 35.6)$ \\
\hline Branş & & Okuldaki hizmet süresi & \\
\hline Sinıf Öğretmeni & $194(\% 56.6)$ & $1-5 \mathrm{yll}$ & $211(\% 61.5)$ \\
\hline Branş Öğretmeni & $149(\% 43.4)$ & 6-10 yıl & $82(\% 23.9)$ \\
\hline & & 10 yıl üzeri & $50(14.6)$ \\
\hline Medeni durum & & Eğitim düzeyi & \\
\hline Evli & $216(\% 63)$ & Lisans & $309(\% 90.1)$ \\
\hline Bekar & $127(\% 37)$ & Lisansüstü & $34(\% 9.9)$ \\
\hline
\end{tabular}

Tablo 2'ye göre örneklemde yer alan katılımciların en fazla bulunduğu yaş grubu 31-40 arasıdır (\%39.4), en fazla bulunduğu mesleki kıdem 6-10 yıl (\%36.2), okuldaki hizmet süresine göre en fazla bulunduğu grup 1-5 y1l (\%61.5)'dir. Ayrıca katılımcı öğretmenlerin 194'ü (\%56.6) sinıf öğretmeni, $149^{\prime} \mathrm{u}$ (\%43.4) branş öğretmeni; medeni duruma göre 216's1 (\%63) evli, 127'si (\%37) bekar; eğitim düzeyine göre ise 309'u (\%90.1) lisans, 34'ü (\%9.9) lisansüstü eğitim düzeyine sahiptir.

\section{Veri Toplama Aracı}

Araştırma sürecine başlarken öğretmenlerin örgütsel bağlllıkları üzerinde etkili olduğu düşünülen faktörlere yönelik alanyazın taraması yapılmıştır. Yapilan taramanın ardından Maroco, Maroco, Campos ve Fredricks (2016) tarafından geliştirilen ve Gün, Turabik, Arastaman ve Akbaşlı (2019) tarafından Türkçe'ye uyarlanan Üniversite Öğrencilerinin Okul Bağhllı̆̆ı Ölçeği'nde yer alan maddeler doğrultusunda 20 maddeden oluşan bir ölçme aracı hazırlanmıştır. Hazırlanan maddeler üç farklı üniversitede görev yapan alan uzmanlarına gönderilerek kapsam geçerliliği için görüş alınmıştır. Kamu ve özel okullarda görev yapan 160 öğretmene pilot uygulama yapılarak maddelerin açık ve anlaşılırlığı test edilmiştir. Pilot uygulama sonunda madde sayısı 15'e düşürülmüşsür. Ayrıca pilot çalışmadan elde edilen veriler üzerinde yapı 
geçerliliğini sağlamak amacıyla faktör analizi yapılmıştır. Açımlayıc faktör analiz sonuçlarına göre iki faktörün yer alması gerektiği görülmüştür. Ancak yapılan analizlerde 13 maddenin ayn faktörde, bir maddenin farklı faktörde, bir maddenin de her iki faktörde yer aldığı tespit edilmiştir. Her iki faktörde yer alan maddenin faktör yükleri arasındaki farkın fazla olması nedeniyle ikinci faktörde yer almasına karar verilmiştir. Alan uzmanlarının görüşlerine göre bu faktörler; davranışsal bağ lılık ve duyuşsal bağ lılık olarak isimlendirilmiştir. Karar verilen son analize göre iki faktör toplam varyansın \%77.292'sini açıklamaktadır. Hazırlanan veri toplama aracının Cronbach Alpha değeri .81 olarak hesaplanmıştır. Böylece araştırmada veri toplamak amacıyla Kişisel Bilgi Formu ve öğretmenlerin örgütsel bağlllık düzeylerini ölçmek üzere hazırlanan 15 maddelik iki faktörlü ölçme aracı kullanılmıştır. Kullanılan ölçme aracında yer alan maddeler 5'li likert tipindedir. Her bir madde için öğrenci tercihlerine sunulmak üzere "Kesinlikle Katılmiyorum", "Katılmıyorum", "Fikrim Yok", "Katılıyorum”, “Kesinlikle Katılıyorum” şeklinde beş derece belirlenmiştir.

\section{Bulgular}

Araştırmanın birinci alt sorusu olan "Çalıştığı kurumda farklı hizmet sürelerine sahip sınıf ve branş öğretmenlerinin örgütsel bağl1lık düzeyleri arasında anlamlı bir fark var mıdır?" sorusuna Faktöryel ANOVA analizi yapılarak yanıt aranmıştır. Faktöryel ANOVA yapmadan önce bu analizin ön koşullarının sağlanıp sağlanmadığı incelenmiştir. Normalliğe ilişkin yapılan analiz sonucunda Skewness $=1.04$ ve Kurtosis $=.25$ olarak hesaplanmıştır. Levene test istatistiği değeri .052 olarak hesaplanmıştır. Böylece normallik ve homojenlik şartının sağlandığı görülmüştür. Ayrıca verilere ait kutu grafiklerine de bakılarak verilerin normal dağılım gösterdiği belirlenmiştir. Verilere ait kutu grafikleri Şekil 3 'te gösterilmiştir. 

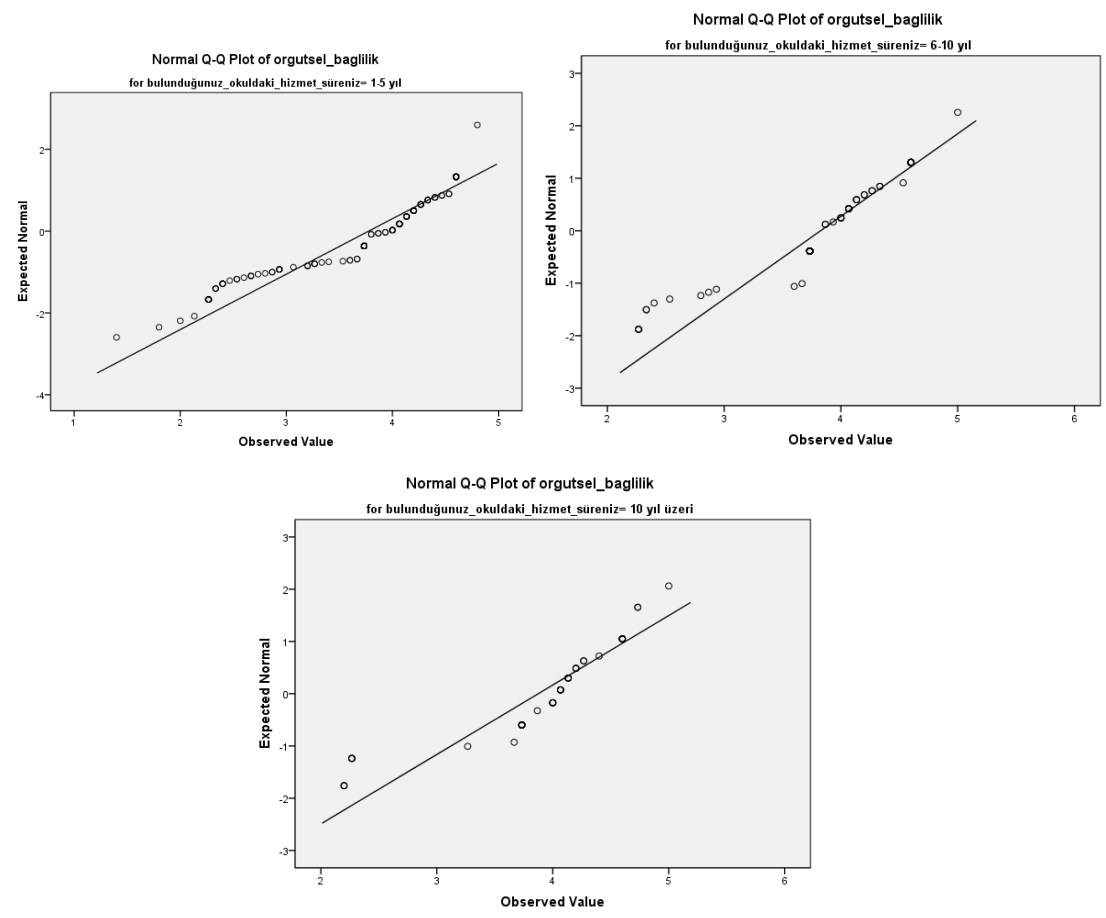

Şekil 3. Verilere ait normallik grafikleri

Kategorik bağımsız değişkenlere göre öğretmenlerin örgütsel bağlılık düzeyi puanlarına ait betimsel istatistikler Tablo 3'te gösterilmiştir.

Tablo 3. Çalıştı̆̆ı Kurumdaki Hizmet Süreleri ve Branşa Göre Örgütsel Bağhllık Düzeyi Puanlarmın Betimsel İstatistikleri

\begin{tabular}{|c|c|c|c|c|c|c|c|c|c|}
\hline \multirow{2}{*}{$\begin{array}{l}\text { Çalıştığı Kurumdaki Hizmet } \\
\text { Süresi }\end{array}$} & \multicolumn{3}{|c|}{ Sınıf Öğretmeni } & \multicolumn{3}{|c|}{ Branş Öğretmeni } & \multicolumn{3}{|c|}{ Toplam } \\
\hline & $\mathrm{N}$ & $X$ & ss & $\mathrm{N}$ & $X$ & SS & $\mathrm{N}$ & $X$ & SS \\
\hline $1-5 \mathrm{y} 1 \mathrm{l}$ & 129 & 3.98 & .83 & 82 & 3.90 & .77 & 211 & 3.95 & .80 \\
\hline $6-10$ y1l & 43 & 4.12 & .55 & 39 & 3.90 & .78 & 82 & 4.02 & .68 \\
\hline 10 yıl üzeri & 22 & 4.15 & .70 & 28 & 3.86 & .83 & 50 & 3.99 & .78 \\
\hline Toplam & 194 & 4.03 & .76 & 149 & 3.90 & .78 & 343 & 3.97 & .77 \\
\hline
\end{tabular}

Tablo 3’e göre çalıştığı kurumda 1-5 yıl hizmet süresine sahip öğretmenlerin örgütsel bağlılık düzeyi ortalama puanı $X=3.95$, 6-10 yıl hizmet süresine sahip öğretmenlerin aynı test ortalama puanı $X=4.02$ ve 10 yıl üzeri hizmet süresine sahip öğretmenlerin ayn test ortalama puanı $X=3.99^{\prime}$ dur. Bu 
gruplardaki öğretmenlerin örgütsel bağlllık düzeyi ortalama puanları arasındaki fark anlamlı bulunmamıştır, $\mathrm{F}(2$ 337)=.29, p>.05. Yani öğretmenlerin çalıştığ1 kurumdaki hizmet süresi, onların örgütsel bağlllık düzeylerinde anlamlı bir farklılığa yol açmamıştır. Öğretmenlerin örgütsel bağlllık düzeylerinin branşa göre anlamlı bir farklılık gösterdiği bulunmuştur $F\left(\begin{array}{ll}1 & 337\end{array}\right)=3.87$, $\mathrm{p}<.05$. Araştırmaya katılan sınıf öğretmenlerinin örgütsel bağlllık düzeyi ortalama puanı $(X=4.03)$, branş öğretmenlerinin ayn test puanlarından $(X=3.90)$ daha yüksektir. Bu bulgu, ögretmenlerin örgütsel bağlllık düzeyleri üzerinde branşın önemli bir etken olduğunu gösterir. Kategorik bağımsız değişkenlere göre öğretmenlerin örgütsel bağlllık düzeyi puanlarına ait faktöryel Anova sonuçları Tablo 4'te gösterilmiştir.

Tablo 4. Çalıştığı Kurumdaki Hizmet Süreleri ve Branşa Göre Örgütsel Bağlılık Düzeyi Puanlarının Faktöryel ANOVA Sonuçları

\begin{tabular}{lllllll}
\hline Varyansın Kaynağı & $\begin{array}{l}\text { Kareler } \\
\text { Toplami }\end{array}$ & Sd & $\begin{array}{l}\text { Kareler } \\
\text { Ortala- } \\
\text { ması }\end{array}$ & $\mathbf{F}$ & $\mathbf{p}$ & $\begin{array}{l}\text { Kısmi } \\
\text { Eta Kare }\end{array}$ \\
\hline Branş & 2.301 & 1 & 2.301 & 3.87 & $.049^{*}$ & .011 \\
$\begin{array}{l}\text { Çalı̧̧ı̆̆ Kurumdaki } \\
\text { Hizmet Süresi }\end{array}$ & .340 & 2 & .170 & .29 & .751 & .002 \\
BxH & & & & & & \\
Hata & .602 & 2 & .301 & .51 & .603 & .003 \\
Toplam & 200.169 & 337 & .594 & & & \\
\hline
\end{tabular}

${ }^{*} \mathrm{p}<.05$

Çalıştığı kurumdaki hizmet süresi ve branşın, öğretmenlerin örgütsel bağlılık düzeyleri üzerindeki ortak etkisinin anlamlı olmadığ bulunmuştur F(2 $337)=.51, \mathrm{p}>$.05. Yani çalıştı̆̆ kurumda farklı hizmet sürelerine sahip öğretmenlerin örgütsel bağlılık düzeyi ortalama puanlarının, branşa; sınıf ya da branş öğretmenlerinin aynı test puanlarının ise çalıştığı kurumdaki hizmet süresine göre farklılık göstermediği anlaşılmaktadır. Kısmi eta kare değişkeni incelendiğinde, branşın örgütsel bağlllık düzeyi üzerinde orta $(0.07<\eta 2<0.13)$, çalıştığı kurumdaki hizmet süresinin düşük $(\eta \mathbf{2}<.06)$ ve BxH'nin örgütsel bağlılık düzeyi üzerinde düşük etkiye ( $\boldsymbol{\eta} 2<.06)$ sahip olduğu anlaşılmaktadır. Bu durumun ortaya çıkmasında kategorilerde yer alan öğretmen sayılarının aynı olmaması etkili olmuş olabilir. 
Araştırmanın ikinci alt sorusu olan "Farklı yaş grubunda yer alan kadın ve erkek öğretmenlerin örgütsel bağlılık düzeyleri arasında anlamlı bir fark var mıdır?" sorusuna faktöryel ANOVA analizi yapılarak yanıt aranmıştır. Faktöryel ANOVA yapmadan önce bu analizin varsayımları test edilmiştir. Levene test istatistiği değeri .155 olarak hesaplanmıştır. Böylece faktöryel Anova için şartların sağlandığı görülmüştür. Verilere ait normallik grafikleri Şekil 4'te gösterilmiştir.

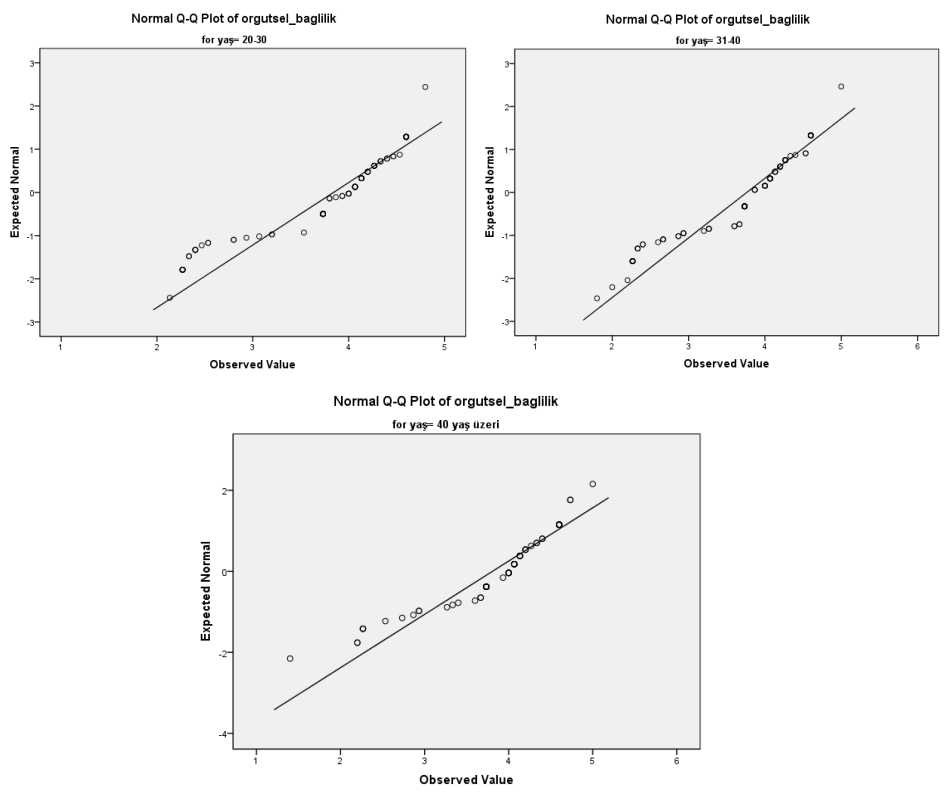

Şekil 4. Verilere ait normallik grafikleri

Yaş ve cinsiyete göre öğretmenlerin örgütsel bağlllık düzeyi puanlarına ait betimsel istatistikler Tablo 5 'te gösterilmiştir.

Tablo 5. Yaş ve Cinsiyete Göre Örgütsel Bağlllk Düzeyi Puanlarnın Betimsel İstatistikleri

\begin{tabular}{lllllllllll}
\hline \multirow{2}{*}{$\begin{array}{l}\text { Çalıştı̆̆ Kurumdaki Hizmet Sü-- } \\
\text { resi }\end{array}$} & \multicolumn{1}{l}{ Kadın } & \multicolumn{3}{l}{ Erkek } & \multicolumn{5}{c}{ Toplam } \\
\cline { 2 - 11 } & $\mathrm{N}$ & $\mathrm{X}$ & ss & $\mathrm{N}$ & $\mathrm{X}$ & ss & $\mathrm{N}$ & $\mathrm{X}$ & ss \\
\hline $20-30$ & 93 & 4.04 & .82 & 42 & 4.02 & .62 & 135 & 4.04 & .76 \\
\hline $31-40$ & 104 & 3.95 & .74 & 41 & 3.88 & .88 & 145 & 3.93 & .78 \\
\hline 40 yaş üzeri & 39 & 3.96 & .76 & 24 & 3.88 & .79 & 63 & 3.93 & .77 \\
\hline Toplam & 236 & 3.99 & .78 & 107 & 3.94 & .76 & 343 & 3.97 & .77 \\
\hline
\end{tabular}


Tablo 5'e göre 20-30 yaş aralığındaki öğretmenlerin örgütsel bağlılık düzeyi ortalama puanı $X=4.04,31-40$ yaş aralığındaki öğretmenlerin aynı test ortalama puanı $X=3.93$ ve 40 yaş üzeri yaş aralığındaki öğretmenlerin aynı test ortalama puanı $\mathrm{X}=3.93$ 'dir. Bu yaş aralıklarındaki öğretmenlerin örgütsel bağlılık düzeyi ortalama puanları arasındaki fark anlamlı bulunmamıştır, F(2 $337)=.756, p>.05$. Yani öğretmenlerin yaşı, onların örgütsel bağlılık düzeylerinde anlamlı bir farklılı̆ga yol açmamıştır. Öğretmenlerin örgütsel bağlılık düzeylerinin cinsiyete göre anlamlı farklılık göstermediği bulunmuştur $\mathrm{F}(1$ $337)=.328, p>.05$. Yaş ve cinsiyete göre öğretmenlerin örgütsel bağlllık düzeyi puanlarına ait faktöryel Anova sonuçları Tablo 6'da gösterilmiştir.

\begin{tabular}{lllllll} 
Tablo 6. Yaşa ve Cinsiyete Göre Örgütsel Bağhllık Düzeyi Puanlarının ANOVA Sonuçlan \\
\hline $\begin{array}{l}\text { Varyansın } \\
\text { Kaynağı }\end{array}$ & $\begin{array}{l}\text { Kareler } \\
\text { Toplamı }\end{array}$ & Sd & $\begin{array}{l}\text { Kareler } \\
\text { Ortalaması }\end{array}$ & F & p & $\begin{array}{l}\text { Kismi } \\
\text { Eta Kare }\end{array}$ \\
\hline Yaş & .905 & 2 & .453 & .756 & .470 & .004 \\
Cinsiyet & .196 & 1 & .196 & .328 & .567 & .001 \\
& & & & & & \\
$\begin{array}{l}\text { Yaş*Cinsiyet } \\
(\text { YxC) }\end{array}$ & .049 & 2 & .025 & .041 & .960 & .000 \\
Hata & & & & & & \\
Toplam & 201.648 & 337 & .598 & & & \\
\hline
\end{tabular}

Yaş ve cinsiyetin, öğretmenlerin örgütsel bağlllık düzeyleri üzerindeki ortak etkisinin anlamlı olmadığı bulunmuştur $\mathrm{F}(2$ 337)=.041, p>.05. Yani farklı yaş aralığındaki öğretmenlerin örgütsel bağlllık düzeyi ortalama puanlar1nın, cinsiyete; kadın ya da erkek öğretmenlerin aynı test puanlarının ise yaşa göre farklılık göstermediği anlaşılmaktadır. Kısmi eta kare değişkeni incelendiğinde, yaşın, cinsiyetin ve yaş ${ }^{*}$ cinsiyetin ortak etkisinin örgütsel bağlllık düzeyi üzerinde düşük ( $\mathbf{\eta} 2<.06)$ etkiye sahip olduğu anlaşılmaktadır.

Araştırmanın üçüncü alt sorusu olan "Çalıştığı okul türü, medeni durum, eğitim düzeyi ve mesleki kıdemin öğretmenlerin örgütsel bağlllık düzeyleri üzerinde anlamlı bir etkisi var mıdır?" sorusuna nicel veri analizi yapılarak yanıt aranmıştır. Bağımlı ve bağımsız değişkenler arasındaki ilişkilere yönelik analiz yapılırken; bağımsız değişkenin iki kategorili olduğu durumlarda bağımsız gruplar t-testi; bağımsız değişkenin ikiden fazla kategorili olduğu durumlarda tek yönlü varyans analizi (ANOVA) kullanılmıştır. Analiz 
sürecine Levene test istatistiği de dahil edilmiştir. Homojenliğin sağlanamadığı durumlarda Welch test istatistiği dikkate alınmıştır.

Tablo 7. Öğretmenlerin Örgütsel Bağlllık Düzeylerinin Kategorik Değiş̧kenlerle Karşılaştırnlmasına Yönelik ANOVA ve T-Testi Sonuçlan

\begin{tabular}{lllllll}
\hline Değişken & Kategoriler & $\mathbf{n}$ & $\overline{\mathbf{X}} \pm \mathbf{S}$ & $\mathbf{F} / \mathbf{t}$ & $\mathbf{p}$ & $\begin{array}{l}\text { Anlamlı } \\
\text { Fark }\end{array}$ \\
\hline Medeni Durum & Evli & 216 & $3.97 \pm .77$ & $\mathrm{t}=-.003$ & .998 & \\
& Bekar & 127 & $3.97 \pm .77$ & & & \\
Eğitim Düzeyi & Lisans & 309 & $3.97 \pm .78$ & $\mathrm{t}=-.020$ & .984 & \\
& Lisansüstü & 34 & $3.97 \pm .73$ & & & \\
Okul Türü & Özel $^{\mathrm{a}}$ & 292 & $4.02 \pm .76$ & $\mathrm{t}=2.524$ & .012 & $\mathrm{a}>\mathrm{b}$ \\
& Kamu $^{\mathrm{b}}$ & 51 & $3.72 \pm .77$ & & & \\
& & & & & & \\
Kidem & $1-5$ yll & 97 & $3.94 \pm .9$ & $\mathrm{~W}=.205$ & .801 & \\
& 6-10 yıl & 124 & $4.01 \pm .74$ & & & \\
& 10 yıl üzeri & 122 & $3.97 \pm .69$ & & & \\
\hline
\end{tabular}

p $<0.05 \quad \mathrm{~W}$ : Varyansların homojenliği ret edildiğinde kullanılan Welch istatistiği

Bağımlı değişken olan öğretmenlerin örgütsel bağlılık düzeyleri ortalamaları incelendiğinde; özel okulda çalışan öğretmenlerin kamuya bağlı okullarda çalışan öğretmenlere göre, 6-10 yıl arası kıdeme sahip olan öğretmenlerin 1-5 yıl ve 10 yıl üzeri kıdeme sahip öğretmenlere göre örgütsel bağlllık düzeylerinin daha yüksek olduğu görülmektedir. Bu durum, özel okulların okul iklimiyle ve meslekteki verimli yılların 6-10 yıl arasında olmasıyla ilişkilendirilebilir. Tablo 7'ye göre öğretmenlerin örgütsel bağlılık düzeyi puan ortalamalarını; medeni durum ( $t=.003 ; p>0.05)$, eğitim düzeyi $(t=.020 ; p>0.05)$ ve mesleki kıdem $(\mathrm{W}=.205 ; \mathrm{p}>0.05)$ değişkenlerine göre istatistiksel olarak anlamlı bir fark oluşturmadığı tespit edilmiştir. Araştırma örnekleminde yer alan öğretmenlerin örgütsel bağlllık düzeyi puan ortalamalarının çalıştı̆̆1 okul türü ( $\mathrm{t=2.524;} \mathrm{p}<0.05)$ değişkenine göre istatistiksel olarak farklılık gösterdiği tespit edilmiştir. Bu durum özel okullarda veli-okul idaresi ve öğrencilerin, öğretmenlere yönelik beklentilerinin ve okulun eğitim-öğretim imkanlarının farklı olmasından kaynaklanıyor olabilir.

\section{Tartışma ve Sonuç}


Özel ve kamu kurumlarında görev yapan öğretmenlerin çalıştığı kurumdaki hizmet süresi, onların örgütsel bağlllık düzeyleri üzerinde önemli bir etkiye sahip değildir. Çalıştığı kurumda 1-5 yıl, 6-10 yıl ve 10 yıl üzeri hizmet süresine sahip öğretmenlerden en düşük örgütsel bağlllık düzeyi puan ortalamasının 1-5 yıl kategorisindeki öğretmenlere ait olduğu tespit edilmiştir. Akan ve Kılıça (2019) göre, örgütleri ve örgüt üyelerinin birbirleri ile olan etkileşimlerini etkileyen; motivasyon, karara katılma, moral durumları, yaşanılan çatışmalar gibi pek çok farklı faktör vardır. Tüm bu etkileşimlerin yaşanması için belli bir süre aynı kurumda çalışmak gerekmektedir. Ortaya çıkan bu sonuç, aynı kurumda daha az hizmet süresine sahip öğretmenlerin, daha az etkileşim yaşamalarına bağlı olarak örgütsel bağlılık düzeylerinin de düşük çıkmasını açıklar niteliktedir.

Araştırma bulgularından elde edilen bir diğer sonuç, öğretmenlerin örgütsel bağlllık düzeylerinin sınıf ya da branş öğretmeni oma durumuna göre farklılaşmamasıdır. Bu sonucun ortaya çıkmasında, öğretmenlerin çalıştıkları kademeye göre branş ya da sınıf öğretmeni olma şeklinde kategorilendirilmeleri etkili olmuş olabilir. Öğretmenlerin aynı kademe kapsamında branşlarına göre farklı kategorilere ayrıldıkları araştırmalardan elde edilen sonuçların istatistiksel olarak anlamlı farklılıklar oluşturmaması elde edilen bu sonucun ortaya çıkmasını destekler niteliktedir. Örneğin; Akyol, Atan ve Gökmen'in (2013) araştırmasında branşlar arasında anlamlı bir fark bulunmamıştır. Nacar ve Demirtaş'ın (2017) lise öğretmenleri ile yürüttüğü araştırmada da yaş, hizmet yılı ve branşın örgütsel bağlılık düzeyleri üzerinde anlamlı bir etkiye sahip olmadığı belirlenmiştir. Öte yandan çalıştı̆̆ kurumdaki hizmet süresi ve branşın birlikte ortak etkisinin, öğretmenlerin örgütsel bağlllık düzeyleri üzerinde anlamlı olmadığı bulunmuştur. Yani çalıştığı kurumda farklı hizmet sürelerine sahip öğretmenlerin örgütsel bağlllık düzeyi ortalama puanlarının, branşa; sınıf ya da branş öğretmenlerinin aynı test puanlarının ise çalıştı̆̆ kurumdaki hizmet süresine göre farklılık göstermediği belirlenmiştir.

Öğretmenlerin yaşı, onların örgütsel bağlllık düzeyleri üzerinde önemli bir etkiye sahip değildir. Ayrıca öğretmenlerin örgütsel bağlılık düzeyleri üzerinde cinsiyet te önemli bir etkiye sahip değildir. Elde edilen bu sonuç, Pelit, Boylu ve Güçer (2007); Güçlü ve Zaman (2011) 'in araştırma sonuçlarıyla örtüşmektedir. Çetin Gürkan'ın (2006) akademisyenlerle yürüttüğü 
araştırmasında da cinsiyet ve yaş, örgütsel bağll1ı̆ın alt boyutlarının algılanmasında anlamlı farklılık oluşturmamıştır. Ancak Kurşunoğlu, Bakay ve Tanriöğen'in (2010) araştırmasında cinsiyete göre öğretmenlerin normatif bağlllıklarında erkekler lehine anlamlı farklılık tespit edilirken, yaş değişkenine göre anlamlı bir farklılık bulunamamıştır. Öte yandan Yörük ve Sağban'ın (2012) araştırmasında anlamlı bir fark olmamasına rağmen kadın katılımcıların okul idaresine karşı daha az olumlu oldukları sonucuna ulaşılmıştır. Berkovich (2018) araştırmasında müdür ile öğretmen aynı cinsiyetten olduğunda müdüre hem duyuşsal hem de bilişsel güvenin daha yüksek olduğu sonucuna ulaşmıştır. Aynı araştırmadan elde edilen bir başka sonuç ise kadın öğretmenlerin erkek müdürlere duyuşsal güveninin zaman ile arttı̆̆ olmuştur. Tüm bu sonuçlardan yola çıkarak, öğretmenlerin örgütsel bağlllık düzeylerini artırmak için okul idarelerinin çözüm önerileri geliştirmeleri gerektiği söylenebilir.

Özel okulda çalışan öğretmenlerin kamuya bağlı okullarda çalışan öğretmenlere göre, 6-10 yıl arası kıdeme sahip olan öğretmenlerin 1-5 yıl ve 10 yıl üzeri kıdeme sahip öğretmenlere göre örgütlerine daha bağlı oldukları sonucu elde edilmiştir. Çatal'ın (2019) ilkokul öğretmenleri ile yürüttüğü çalışmasında, ilkokul öğretmenlerinin yaşları arttıkça okullarına olan bağlılıklarının da arttı̆̆ sonucuna ulaşılmıştır. Aynı araştırmada kıdemi 31 ve üstü olan ilkokul öğretmenlerinin örgütsel bağlılık düzeylerinin de daha yüksek olduğu sonucuna ulaşılmıştır. Elde edilen sonuçlar, bu araştırmanın sonuçlarıyla çelişmektedir. Bu durumun ortaya çıkmasında mesleki kıdem kategorilerinin Çatal'ın (2019) belirlediği mesleki kıdem kategorilerinden farklı olarak; 1-5, 6-10, 10 yıl ve üzeri şeklinde belirlenmesinin etkisi olmuş olabilir. Öğretmenlerin örgütsel bağlılık düzeyi puan ortalamalarının; medeni durum, eğitim düzeyi ve mesleki kıdem değişkenlerine göre istatistiksel olarak anlamlı bir fark oluşturmadığı tespit edilmiştir. Ancak araştırma örnekleminde yer alan öğretmenlerin örgütsel bağlllık düzeyi puan ortalamalarının çalıştığı okul türü değişkenine göre özel okulda çalışan öğretmenler lehine istatistiksel olarak farklılık gösterdiği tespit edilmiştir. Durna ve Eren'in (2005) eğitim ve sağlık sektöründe çalışan personellerle yürüttüğü araştırmasında, medeni hali evli olan çalışanların örgütsel bağlllıklarının daha yüksek olduğu sonucuna ulaşılmıştır. Bu araştırmada medeni durum değişkenine göre anlamlı farklılık tespit edilememesi, örneklemde yer alan tüm öğretmenlerin eğitim sektöründe çalışanlar olmasından kaynaklanıyor olabilir. 
Sonuç olarak araştırmada, kamu ve özel kurumlarında çalışan öğretmenlerin örgütsel bağlllık düzeylerinin sınıf öğretmenleri lehine anlamlı olarak farklılaştığı ve çalıştığı okul türüne göre özel okulda çalışan öğretmenler lehine anlamlı olarak farklılaştığı belirlenmiştir. Ulaşılan bu sonuçlar branşın ve görev yapılan okul türünün, öğretmenlerin örgütsel bağlılık düzeyleri üzerinde önemli bir değişken olduğunu göstermektedir. Farklı değişkenlere göre öğretmenlerin örgütsel bağlılık düzeylerinde anlamlı ya da anlamlı olmayan farklılıkların detaylı bir şekilde incelenmesi gerekmektedir. Çünkü öğretmenlerin ve okulun performansını yükseltmede, örgütsel bağlılık önemli bir unsurdur (Tulunay Ateş ve Buluç, 2018). Bu nedenle öğretmenlerin örgütsel bağlllık düzeylerini artırmaya yönelik kurumların kendi bünyesinde gerekli araştırmalar yaparak çözümler üretmesi ve konuyu daha derinlemesine ele alabilecek nitel araştırmalar yapılması önerilmektedir. 


\title{
EXTENDED ABSTRACT
}

\section{Organizational Commitment Levels of Teachers Working in Private and Public Institutions: The Interactive Impact Model}

\author{
Lütfi Üredi - Sait Akbaşl1 - Pelin Kösece - Burak Özaksoy \\ Mersin University - Hacettepe University - MONE - Doğa Schools
}

The workers' commitment to the organization has to continue so that the organization survives. The feeling of the commitment to the organization positively influences the workers' performances and hence the performance of the organization. The workers' level of organizational commitment should be as high as possible in order to reduce the discipline problems and absenteeism in the organization and gain more production and higher efficiency.

Today, there is an unstable change and development in a great deal of fields such as the economic, social, cultural and scientific fields. The skills expected from the people who are the components which the developments in the society directly influence change. Each of the educational institutions, which are one of the institutions that influence the society, constitutes the educational organizations. Organizational commitment of the teachers, who are one of the basic components of educational organizations, has considerable influence on the progress and development of educational institutions. In the researches, it is seen that the variables of gender, marital status, age and seniority influence the teachers' organizational commitment at varying degrees. In addition to these variables, it is expected that this research, in which the length of service in the institution and seniority are dealt with separately, in which the common effects of the variables on organizational commitment are analysed and in which the effect of being primary school teacher and branch teacher on organizational commitment are investigated, contributes to filling the void in the literature. This research is important as it deals with the interactional effect of different variables, working in private and public institutions, seniority and length of service in the school and being a primary school teacher and branch teacher separately. It is thought that the results gained will 
contribute to the studies of the teachers' professional development. In the research, the sub-questions below are aimed to be answered:

- Is there a significant difference among the primary school teachers and branch teachers who have different length of service in the institutions in which they work in terms of their level of organizational commitment? (BxH)

- Is there a significant difference among the female and male teachers who are in different age groups in terms of their level of organizational commitment? (YxC)

- Do the type of school in which the teachers work, marital status, educational level and professional seniority have significant effect on the teachers' organizational commitment?

The quantitative research methods were used in this research. The interactional effect of some variables on the organizational commitment of teachers working in educational institutions were analysed by means of correlational survey model. The population of the research was composed of the teachers working in private and public schools in Ankara. While determining the sample of the research, random sampling, which was one of the methods of probability sampling, was used. As it wasn't possible to reach all of the teachers in the population, a sample, which was smaller and which could be reached, was chosen from the population. As the research was carried out in the city, the sample was chosen from 55.000 people, which constituted the population with 0.5 deviation ration. The research data were collected in the fall semester of 2019-2020 academic year. The participants were determined according to the voluntariness. Before the research, the participants were informed that the data collected would just be used within the scope of this research and the information would be kept confidential. At the beginning of the research process, literature scanning was performed in relation to the factors, which were thought to have influence on the teachers' organizational commitment. After the scanning, the scale, which was developed by Maroco, Maroco, Campos ve Fredricks (2016) and which was adapted for Turkish by Gün, Turabik, Arastaman ve Akbaşl1 (2019) and which included 20 items existing in University Student Engagement Inventory, was prepared. The items prepared were sent to domain experts working in 3 different universities and their opinions about the content validity were got. A pilot study was 
performed with 160 teachers working in the public and private schools and the clarity and explicitness of the items were tested. It was calculated that the Cronbach Alpha value of the data collection tool was .81. Consequently, Personal Information Form and two-factor measurement instrument, which was prepared in order to measure the teachers' organizational commitment and which had 15 items, were used to collect the data in the research. The measurement instrument, which was used, was 5 point likert scale.

According to the findings of the research, the length of service of the teachers working in private and public schools didn't have a significant effect on their organizational commitment. It was determined that the teachers, whose length of service was in the category of 1-5 year, had the lowest level of organizational commitment among the teachers who had 1-5 year length of service, 6-10 year length of service and who had length of service over 10 years. Another result obtained from the findings of the research was that the teachers' level of organizational commitment didn't differ according to their becoming primary school teachers or branch teachers. The result can stem from the fact that the teachers were categorized as branch teachers or primary school teachers according to the organization where they worked. The fact that the research results weren't statistically significant in the researches in which the teachers were categorized according to their branches supported this result of the research. For example, a significant difference among the branches wasn't found in the research, which was performed by Akyol, Atana and Gökmen (2013). In the research, in which Nacar and Demirtass (2017) carried out with high school teachers, it was also determined that age, length of service and branch didn't have a significant effect on organizational commitment. Moreover, it was found out that common effect of length of service in the institution where the teachers work and branch didn't have a significant effect on the teachers' organizational commitment. Teachers' age didn't have a significant effect on the their organizational commitment. Additionally, teachers' gender didn't have a significant effect on their organizational commitment. This result obtained overlaps the results of the researches performed by Pelit, Boylu and Güçer (2007); Güçlü and Zaman (2011). As a result, it was determined that there was a significant difference among the teachers working in public and private institutions 
according to being primary school teacher and branch teacher in terms of organizational commitment and the primary school teachers' level of organizational commitment was higher than branch teachers and it was also determined that there was a significant difference according to the type of school where the teachers worked and the teachers working in private schools have higher levels of organizational commitment than the teachers working in public schools.

\section{Kaynakça / References}

Ahuja, S. ve Gupta, S. (2019). Organizational commitment and work engagement as a facilitator for sustaining higher education professionals. International Journal of Recent Technology and Engineering, 7(6), 1846-1851.

Akan, D. ve Kulıç, M. E. (2019). Öğretmenlerin örgütsel bağlllık düzeyleri ile okul etkililiği arasındaki ilişkinin incelenmesi. Ekev Akademi Dergisi, (80), 123-136.

Akyol, P., Atan, T. ve Gökmen, B. (2013). Beden eğitimi ve sını öğretmenlerinin örgütsel bağlllık düzeylerinin incelenmesi. Spor ve Performans Araştırmaları Dergisi, 4(1), 38-45.

Ateş, Ö. T. ve Buluç, B. (2018). İlköğretim öğretmenlerinde motivasyon ve örgütsel bağlllı̆̆ın demografik değişkenler açsından incelenmesi. Mehmet Akif Ersoy Üniversitesi Ĕ̆itim Fakültesi Dergisi, (48), 1-30.

Bayram, L. (2005). Yönetimde yeni bir paradigma: örgütsel bağlllık. Sayıştay Dergisi, 59, 125-139.

Berberoğlu, A. (2018). Impact of organizational climate on organizational commitment and perceived organizational performance: empirical evidence from public hospitals. BMC Health Services Research, 18(1), 399.

Berkovich, I. (2018). Effects of principal-teacher gender similarity on teacher's trust and organizational commitment. Sex Roles, 78(7-8), 561-572.

Celep, C. (2014). Eğitim örgütlerinde örgütsel adanma. Ankara: Nobel Yayınclık.

Chor, L. T. (1991). Development of organizational commitment in Hong Kong aided secondary school christian teachers -- a case study. 09.01.2021 tarihinde http://www.fed.cuhk.edu.hk/ceric/cuma/91tcleung/conclusion.htm adresinden erişildi.

Çatal, M. (2019). İlkokul öğretmenlerinin örgütsel bağhllk düzeylerinin incelenmesi. Tezsiz yüksek lisans projesi, Pamukkale Üniversitesi, Eğitim Bilimleri Enstitüsü, Denizli. 
Çetin Gürkan, G. (2006). Örgütsel bağhllık: örgütsel iklimin örgütsel bağhllık üzerindeki etkisi ve Trakya Üniversitesi'nde örgüt iklimi ile örgütsel bağhllı arasindaki ilişkinin araştırılması. (Yüksek lisans tezi) Ulusal Tez Merkezi (206826)

Çoban, D. ve Demirtaş, H. (2011). Okulların akademik iyimserlik düzeyi ile öğretmenlerin örgütsel bağlılığı arasındaki ilişki. Kuram ve Uygulamada Egitim Yönetimi Dergisi, 17(3), 317-348.

Çolakoğlu, Ü., Ayyıldız, T. ve Cengiz, S. (2009). Çalışanların demografik özelliklerine göre örgütsel bağlılık boyutlarında algılama farklılıkları: Kuşadası'ndaki beş yıldızlı konaklama işletmeleri örneği. Anatolia: Turizm Araştırmaları Dergisi, 20(1), 77-89.

Dou, D., Devos, G. ve Valcke, M. (2017). The relationships between school autonomy gap, principal leadership, teachers' job satisfaction and organizational commitment. Educational Management Administration E Leadership, 45(6), 959-977.

Durna, U. ve Eren, V. (2005). Üç bağllik unsuru ekseninde örgütsel bağlllık. Doğus Üniversitesi Dergisi, 6(2), 210-219.

Faraji, M. ve Begzadeh, S. (2017). The relationship between organizational commitment and spiritual intelligence with job performance in physical education staff in east Azerbaijan province. International Journal of Management, Accounting and Economics, 4(5), 565-577.

Güçlü, N. ve Zaman, O. (2011). Alan dışından atanmış rehber öğretmenlerin iş doyumları ile örgütsel bağlılıkları arasındaki ilişki. Türk Ĕ̆itim Bilimleri Dergisi, 9(2), 541-576.

Gün, F., Turabik, T., Arastaman, G. ve Akbaşl1, S. (2019). Adaptation of university student engagement inventory to Turkish culture: Validity and reliability study. Inonu University Journal of the Faculty of Education, 20(2), 507-520.

İlter, P. (2019). Resmi eğitim kurumlarnda görev yapan rehber öğretmenlerin örgütsel bağhllık ve motivasyon düzeyleri arasındaki ilişki. (Yüksek lisans tezi). Ulusal Tez Merkezi (569422)

John, M. C. ve Taylor, J. W. (1999). Leadership style, school climate, and the institutional commitment of teachers. In International Forum Journal, 2(1), 25-57.

Korkmaz, M. (2011). İköğretim okullarında örgütsel iklim ve örgüt sağlığının örgütsel bağlılık üzerindeki etkisi. Kuram ve Uygulamada Egitim Yönetimi Dergisi, 17(1), 117-139.

Maroco, J., Maroco, A. L., Campos, J. A. D. B. ve Fredricks, J. A. (2016). University student's engagement: development of the University Student Engagement Inventory (USEI). Psicologia: Reflexão e Crítica, 29(21), 1-12. 
Nacar, D. ve Demirtaş, Z. (2017). Lise öğretmenlerinin örgütsel bağlllk düzeyleri. Uluslararası Türk Eğitim Bilimleri Dergisi, 2017(9), 547-558.

Nikpour, A. (2017). The impact of organizational culture on organizational performance: The mediating role of employee's organizational commitment. International Journal of Organizational Leadership, 6, 65-72.

Kurşunoğlu, A., Bakay, M. E., ve Tanriöğen, A. (2010). İlköğretim okulu öğretmenlerinin örgütsel bağlllk düzeyleri. Pamukkale Üniversitesi Eğitim Fakültesi Dergisi, 28(2), 101-115.

Pelit, E., Boylu, Y. ve Güçer, E. (2007). Gazi Üniversitesi Ticaret ve Turizm Eğitim Fakültesi akademisyenlerinin örgütsel bağllık düzeyleri üzerine bir araş九trma. Ticaret ve Turizm Eğitim Fakültesi Dergisi, 1, 86-114.

Roncesvalles, M. C. T. ve Gaerlan, A. A. (2020). Authentic leadership and teacher morale: effects on organizational commitment in higher education. International Journal of Advanced Research and Publications, 4(3), 85-94.

Rosenholtz, S. ve Simpson, C. (1990). Workplace conditions and the rise and fall of teachers' commitment. Sociology of Education, 63, 241-257.

Sarıdere, U. (2004). Ĕ̆itim örgütlerinde örgütsel bağhllğgn işten ayrlma niyetine etkisi. (Yüksek lisans tezi). Ulusal Tez Merkezi (147182)

Scholl, R. (2008). What is organizational commitment. Scholl WebNotes.

Uğurlu, C. T. ve Üstüner, M. (2011). Öğretmenlerin örgütsel bağlllık düzeylerineyöneticilerinin etik liderlik ve örgütsel adalet davranışlarının etkisi. Hacettepe Üniversitesi Ĕ̈itim Fakültesi Dergisi, 41(41), 434-448.

Yıldırım, A. ve Şimşek, H. (2013). Sosyal bilimlerde nitel araştrma yöntemleri (9.bs.). Ankara: Seçkin Yayıncllk.

Yörük, S. ve Sağban, Ş. (2012). Okul müdürlerinin kültürel liderlik rollerinin öğretmenlerin örgütsel bağlllık düzeyine etkisi. Electronic Turkish Studies, 7(3).2795-2813.

\section{Kaynakça Bilgisi / Citation Information}

Üredi, L., Akbaşl1, S., Kösece, P. ve Özaksoy, B. (2021) Özel ve kamu eğitim örgütlerinde çalişan öğretmenlerin örgütsel bağlilik düzeyleri: Etkileşimsel etki modeli. OPUS-Uluslararası Toplum Araştırmaları Dergisi , 17(38), 4983-5005. DOI: 10.26466/opus.858602 